\title{
Comparison of Four Different Electronic Pain Rating Scales in Patients with Symptomatic Tooth
}

\author{
Semptomatik Dişlere Sahip Olan Hastalarda Dört Farklı Elektronik Ağrı \\ Değelendirme Skalasının Karşılaştırılması
}

Tan Firat Eyuboglu

Department of Endodontics, School of Dentistry, Istanbul Medipol University, Istanbul, Turkey

Atıf/Citation: Eyuboglu, T.., (2020). Comparison of Four Different Electronic Pain Rating Scales in Patients with Symptomatic Tooth. Ege Üniversitesi Diş Hekimliği Fakültesi Dergisi, 41(3), 195-200.

\section{Öz}

Giriş ve Amaç: Bu çalışmanın amacı, semptomatik dişleri olan hastalarda dört farklı elektronik ağrı skalası arasındaki korelasyonu ve uyum düzeyini değerlendirmekti.

Yöntem ve Gereçler: Semptomatik dişi olan 50 hasta çalışmaya dahil edildi. Hastaların yașı, cinsiyeti, diș tipi kaydedildi. Hastalardan, kanal tedavisi öncesinde elektronik ağrı derecelendirme programında ağrı şiddetlerini dört farklı ağrı skalasında işaretlemeleri istendi; Görsel Analog Skala (VAS), Renk Analog Skalası (CAS), Sayısal Derecelendirme Skalası (NRS) ve Yüz Derecelendirme Skalası (FRS). Daha sonra, ağrı skorlamasındaki korelasyon ve uyum düzeyini değerlendirmek için tüm skorlar istatistiksel analize tabi tutuldu.

Bulgular: Tüm ağrı derecelendirme skalaları arasında pozitif korelasyon bulundu $(p<0.001)$. En yüksek korelasyon CAS ve NRS skorları arasında gözlendi $(r=0.930, p<0.001)$. Ağrı yorumlamasında en yüksek düzeyde uyum CAS ve NRS arasında $(0.685, p$ $<0.001)$, en düşük uyum ise CAS ile FRS arasında (0.384, $p<0.001)$ gözlenmiştir.

Tartışma ve Sonuç: Ağrı derecelendirme prosedürünün öznelliğini gösterecek şekilde, tüm skalalar arasında güçlü bir korelasyon ama orta düzeyde bir uyum bulunmuştur.

Anahtar Kelimeler: Renk analog skalası, yüz derecelendirme skalası, sayısal derecelendirme skalası, ağrı derecelendirme skalası, görsel analog skalası

\section{ABSTRACT}

Introduction: The study aimed was to assess correlation and evaluate the agreement level between four different electronic pain rating scales in patients with symptomatic teeth.

Methods: 50 patients with symptomatic teeth who consented were enrolled for this study. Patients' age, sex, tooth type was recorded. Patients were then asked to mark their pain intensity on four pain rating scales; Visual Analogue Scale (VAS), Color Analogue Scale (CAS), Numerical Rating Scale (NRS) and Faces Rating Scale (FRS) before root canal treatment via an electronic pain rating program. All scores were then subjected to statistical analysis to assess correlation and agreement level in pain interpretation.

Results: A positive correlation was found between all pain rating scales $(p<0.001)$. The highest correlation was observed between CAS and NRS scores $(r=0.930, p<0.001)$. The highest level of agreement in pain interpretation was observed between CAS and NRS $(0.685, p<0.001)$ while, the lowest was between CAS and FRS $(0.384, p<0.001)$.

Discussion and Conclusion: All rating scales presented a strong positive correlation whit a moderate level of agreement between scales indicating subjectivity of pain rating procedure.

Keywords: Color analogue scale, faces rating scale, numerical rating scale, pain rating scale, visual analogue scale 


\section{INTRODUCTION}

Pain is an unpleasant experience with a restrictive effect on the emotional, social, and sensorial aspects of daily routine and therefore, has a diminishing impact on the quality of life. ${ }^{1,2}$ It is the primary reason patients seek endodontic treatment ${ }^{3}$ and a key symptom for assessment and diagnosis of diseases with the endodontic origin. ${ }^{4}$ Thus, pain assessment has been an important aspect of daily clinical practice to create better preventive and treatment procedures. ${ }^{5}$

Pain assessment is well-studied using psychometric assessment techniques and the subjectivity of the pain ratings is validated due to differences among the cognitive abilities of the patients. ${ }^{6}$ Although there are many different pain rating scales, the Visual Analogue Scale (VAS) is one of the most reliable methods and widely studied which is a $10 \mathrm{~cm}$ line with two endpoints; "no pain" and "worst possible pain", 7,8,9

Color Rating Scale (CAS) is particularly used for children between 5 to 16 years old. ${ }^{10}$ Due to its involvement of gradations in length, area, and color it gives an easier association of pain with different pain intensity levels ${ }^{11}$ which has two endpoints; "no pain" and "worst possible pain" such as the VAS score.

Numerical Rating Scale (NRS) is a line with a $0-10$ scale. It can be both vertical and horizontal. " 0 " represents no pain and "10" the worst possible pain. The advantage of this scale is that it can be used verbally or visually, which proved to be beneficial in patients with acute pain or psychomotor disability. ${ }^{12}$ However, the difficulty for patients to visualize their pain in numbers were also reported as a disadvantage of NRS. ${ }^{13}$

Faces rating Scale was provided for children 3 years old and older. ${ }^{14}$ Yet soon its advantages for patients with acute pain, cognitive disabilities, difficulties using numerical rating scales were noticed. ${ }^{15,16}$

Although these pain rating scales were widely studied $^{5,7,14}$ there is no study comparing these scales presented on an electronic pain rating program for dental patients with symptomatic teeth. Therefore, the objectives of this study were to assess the correlation between four pain rating scales (VAS, CAS, NRS, and FRS) and to evaluate the level of agreement between all four scales in means of pain interpretation. The hypothesis was that there is a positive correlation between all four scales with very good level of agreement in pain interpretation.

\section{MATERIALS AND METHODS}

The study was approved by the ethical committee of the university (registration number: 338) and registered to clinicaltrials.gov with the ID number: NCT04231955. All patients were volunteered and singed and written informed consent prior to enrollment.

\section{Inclusion and Exclusion Criteria}

This study included patients who had a symptomatic tooth which was indicated for root canal treatment. All procedures were carried out between April 2019 and December 2019. A total number of 50 patients were enrolled in this study. Age, gender, teeth type, were also recorded as well as the diagnosis in each patient. The diagnosis was made using both clinical and radiological (Kodak RVG 5100; Carestream Health, Inc., Rochester, NY) evaluation. The following patients were excluded from the study: (i) Patients who were under 18 years old, (ii) patients with medical contradictory for sound pain assessment (i.e. being diabetic, being under the influence of corticosteroids, opioids) a, (iii) patients who could not follow the instructions to pain rating scales, (iv) patients who used analgesics 1 week and antibiotics 1 month prior to pain assessment.

\section{Sample Size}

Power analysis was done by using G* Power (v3.1.9) program to determine the sample size. The sample size of 46, for the 2-sided Fisher $\mathrm{z}$ test of the null hypothesis that the Pearson correlation coefficient equals 0 , would be satisfactory to have $80 \%$ power to detect correlations as small as 0.4 . therefore, 50 patients were submitted in this study.

Evaluation of pain according to four different rating scales

All evaluation was made at the first appointment before commencing the root canal treatment. An electronic pain rating scale program (ETZ Pain Assessment and Rating Scales ver. 1.6) was used to evaluate pain on four different pain rating scales in each patient: Visual Analogue Scale (VAS), Color Analogue Scale (CAS), Numerical Rating Scale (NRS) and Faces Rating Scale (FRS).

\section{Visual Analogue Scale (VAS)}

Patients were asked to mark their pain on a $10 \mathrm{~cm}$ vertical line in the program with two endpoints: "no pain” and "worst possible pain” (Fig 1-A).

\section{Color Analogue Scale (CAS)}

Patients were asked to mark their pain on a wedgeshaped figure with a gradually progressing color from white indicating no pain) to red (indicating worst possible pain) (Fig 1-B).

\section{Numerical rating scale}

Patients were asked to mark their pain on a vertical scale from "0" (indicating "no pain”) to "10" (indicating “worst possible pain”) (Fig 1-C).

\section{Faces Rating Scale}

It is a scale of 6 facial expressions. Each expression stands for different intensity of pain with gradually progressing color from green (indicates "no pain”) to red (indicates “worst pain possible”) (Fig 1-D). 


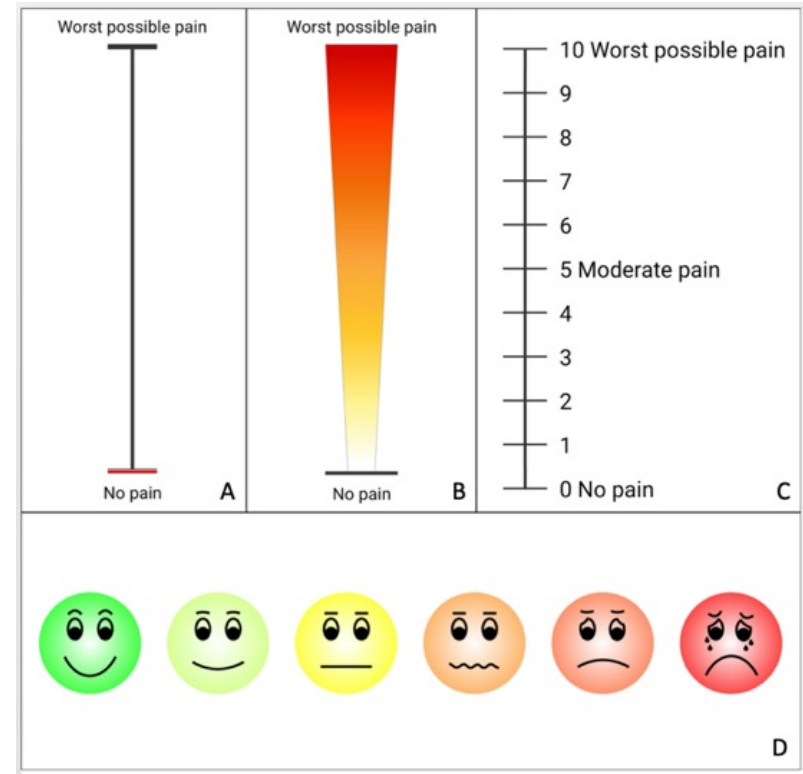

Figure 1. Pain rating scales. A: Visual Analogue Scale, B: Color analogue scale. C: Numerical Rating Scale, D: Faces Rating Scale; the facial expressions were each given a number between "0" (green, "no pain”) and “5” (red, "worst pain possible).

After Patients indicated their pain on VAS and CAS scale the program calculated the exact distance between the mark and the "no pain" endpoint. These calculations were recorded as VAS and CAS scores in $\mathrm{mm}$. The number that the patients marked in NRS was recorded without any conversion, while the marked facial expressions were converted numbers from 0 to 5 in FRS. The values in all four rating scales were also allocated into 4 groups (no pain, mild pain, moderate pain, and severe pain) for interpretation of pain via pain rating scale program (Table 1). The correlation between scales and the level of agreement between allocated scores was evaluated for comparison of scales.

Table 1. The allocation of scores in four groups for interpretation of pain.

\begin{tabular}{lcc} 
& No Pain & Mild Pain \\
\cline { 2 - 3 } VAS & 0 & $1-44$ \\
CAS & 0 & $1-44$ \\
NRS & 0 & $1,2,3$ \\
FRS & 0 & 1,2
\end{tabular}

VAS: Visual Analog Scale, CAS: Color analog Scale, NRS Numerical Rating Scale, FRS: Facial Rating Scale

\section{Statistic Evaluation}

NCSS (Number Cruncher Statistical System) 2007 (Kaysville, Utah, USA) software was used for statistical analysis. Descriptive statistics such as mean, standard deviation, frequency, percentage, minimum, and maximum were used to report the data. The normality of the data was checked by the Shapiro Wilk test. Spearman's rho was used to determine the correlation between scores. Fleiss' kappa was used to assess the level of agreement between scores. A p-value of $<0.05$ accepted as statistically significant. The interpretation of Kappa scores was conducted according to Kappa score interpretation chart as mentioned in a previous study. ${ }^{17}$

\section{RESULTS}

All 50 patients who were submitted to this study were enrolled for the pain rating procedure with no drop-outs. The descriptive statistics are presented in Table 2 and the allocation of pain scores is displayed in Table 3.

Table 2. Descriptive statistics of the data and frequency distribution

\begin{tabular}{llc}
\hline Age & Min-Max & $18-69$ \\
& Mean \pm SD & $36.14 \pm 13.09$ \\
\cline { 1 - 1 } Sex; n(\%) & Female & $35(70)$ \\
& Male & $15(30)$ \\
\cline { 1 - 1 } Jaw; n(\%) & Maxillary & $25(50)$ \\
& Mandibular & $25(50)$ \\
\cline { 1 - 1 } Tooth location; n(\%) & Anterior & $8(16)$ \\
& Premolar & $14(28)$ \\
& Molar & $28(56)$ \\
\cline { 1 - 1 } Diagnosis; n(\%) & AAA & $1(2)$ \\
& AAP & $49(98)$ \\
\hline AAA: acute apical abscess, & AAP: Acute Apical Periodontitis
\end{tabular}

Table 3. Descriptive data of all pain rating scores and the allocation of scores from all four pain rating scales into mild, moderate and severe pain.

\begin{tabular}{lll}
\hline VAS & Min-Max (Median) & $10-100(63)$ \\
& Mean \pm SD & $60.76 \pm 25.78$ \\
VAS; n(\%) & Mild & $16(32)$ \\
& Moderate & $17(34)$ \\
& Severe & $17(34)$ \\
\hline CAS & Min-Max (Median) & $12-100(63.5)$ \\
& Mean $\pm S D$ & $63.38 \pm 23.09$
\end{tabular}

$\begin{array}{lll}45-74 & 75 \text { Mdderate } & 23(46) \\ 45-74 & 75 \text { Sevefe } & 17(34)\end{array}$

4, 5, TrS 7,9-9h10 2-10 (6) Mean \pm SD $\quad 6.12 \pm 2.35$

NRS; n(\%) Mild 9 (18)

\begin{tabular}{lll} 
& Moderate & $19(38)$ \\
& Severe & $22(44)$ \\
\hline FRS & Min-Max (Median) & $1-5(3)$ \\
& Mean \pm SD & $3.38 \pm 1.17$ \\
& Mild & $13(26)$ \\
& Moderate & $14(28)$ \\
& Severe & $23(46)$ \\
\hline
\end{tabular}


VAS: Visual Analog Scale, CAS: Color analog Scale, NRS: Numerical Rating Scale, FRS: Facial Rating Scale

A statistically significant relationship was found between all scores $(\mathrm{p}<0.001)$. There was a very strong positive correlation between CAS and NRS scores $(\mathrm{r}=0.930, \mathrm{p}<0.001), \mathrm{VAS}$ and CAS scores $(\mathrm{r}=0.922$, $\mathrm{p}<0.001$ ) (Fig 2), and VAS strong positive correlation between NRS and FRS scores $(r=0.787, \mathrm{p}<0.001)$, VAS and FRS scores $(\mathrm{r}=0.776, \mathrm{p}<0.001)$, and CAS and FRS scores $(\mathrm{r}=0.772, \mathrm{p}<0.001)$.

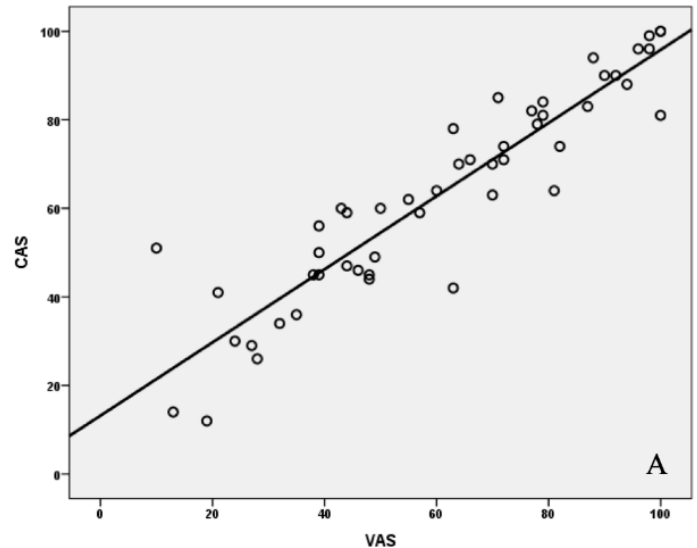

The level of agreement between all scores was moderate with a Kappa score of $0.551(\mathrm{p}<0.001)$. The Agreement level between CAS and NRS scores was good $(0.685, \mathrm{p}<0.001)$, while the agreement levels between VAS and CAS $(0.574, \mathrm{p}<0.001)$, VAS and NRS (0.573, $\mathrm{p}<0.0019)$, VAS and FRS (0.545, $\mathrm{p}<0.001)$, and NRS and FRS (0.531, $\mathrm{p}<0.001)$ were moderate. On the other hand, the agreement level between CAS and FRS was only fair $(0.384, \mathrm{p}<0.001)$ (Table

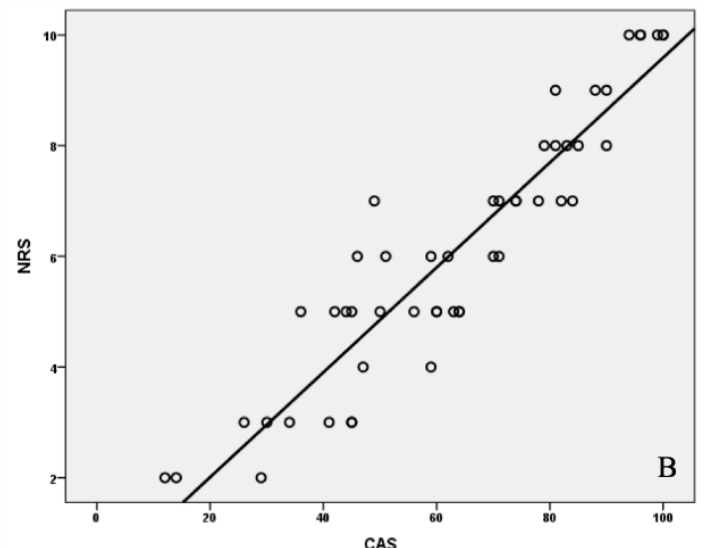

Figure 2. A: The correlation between VAS and CAS scores, B: The correlation between CAS and NRS scores. Both indicated a very strong relationship. VAS: Visual Analog Scale, CAS: Color analog Scale, NRS: Numerical Rating Scale.

Table 4. The agreement level between all four pain rating scales according to pain intensity interpretation levels.

\begin{tabular}{|c|c|c|c|c|c|}
\hline & & VAS & & & \\
\hline & & Mild & Moderate & Severe & Карра, р \\
\hline CAS & Mild & 8 (16) & $2(4)$ & $0(0)$ & \\
\hline & Moderate & $8(16)$ & $13(26)$ & $2(4)$ & 0.574, \\
\hline & Severe & $0(0)$ & $2(4)$ & $15(30)$ & \\
\hline NRS & Mild & $9(18)$ & $0(0)$ & $0(0)$ & \\
\hline & Moderate & 7 (14) & $11(22)$ & $1(2)$ & $\begin{array}{l}0.5 / 3, \\
<0001 * *\end{array}$ \\
\hline & Severe & $0(0)$ & $6(12)$ & $16(32)$ & \\
\hline FRS & Mild & $11(22)$ & $2(4)$ & $0(0)$ & \\
\hline & Moderate & $3(6)$ & $9(18)$ & $2(4)$ & $\begin{array}{l}0.545, \\
<0001 * *\end{array}$ \\
\hline & Severe & $2(4)$ & $6(12)$ & $15(30)$ & \\
\hline & & CAS & & & \\
\hline & & Mild & Moderate & Severe & карра, р \\
\hline NRS & Mild & 7 (14) & $2(4)$ & $0(0)$ & \\
\hline & Moderate & $3(6)$ & $16(32)$ & $0(0)$ & 0.685, \\
\hline & Severe & $0(0)$ & $5(10)$ & $17(34)$ & \\
\hline FRS & Mild & $6(12)$ & $7(14)$ & $0(0)$ & \\
\hline & Moderate & $3(6)$ & 9 (18) & $2(4)$ & $\begin{array}{l}\text { U.384, } \\
0.001 * *\end{array}$ \\
\hline & Severe & $1(2)$ & 7 (14) & $15(30)$ & \\
\hline & & NRS & & & \\
\hline & & Mild & Moderate & Severe & карра, р \\
\hline FRS & Mild & $8(16)$ & $5(10)$ & $0(0)$ & \\
\hline & Moderate & $1(2)$ & 9 (18) & $4(8)$ & $\begin{array}{l}\text { U.531, } \\
<0001 * *\end{array}$ \\
\hline & Severe & $0(0)$ & $5(10)$ & $18(36)$ & $<0.001^{* *}$ \\
\hline
\end{tabular}

Fleiss’ kappa $* * \mathrm{p}<0.01$

VAS: Visual Analog Scale, CAS: Color analog Scale, NRS: Numerical Rating Scale, FRS: Facial Rating Scale 


\section{DISCUSSION}

In this study important information provided about the correlation and the agreement level between four different electronic pain rating scales in patients with symptomatic teeth. According to the results of this study, all pain rating scales had a strong positive correlation. The level of agreement between all electronic pain rating scores was "moderate" (0.551). Therefore, the hypothesis was partially accepted, indicating the level of agreement was not "very good" $(\geq 0.81)$ between different electronic rating scales in acute dental pain, even after subsequent assessment with no time loss between pain assessments with each pain rating scale.

Lately, the use of electronic pain rating scales was introduced into the literature providing promising and supporting data on the validity of electronic pain rating scales. ${ }^{18}$ In a previous study, strong correlation and agreement levels were demonstrated between the paper and electronic versions of VAS, CAS, NRS, and FRS on children. ${ }^{19,20}$ An 80\% confidence interval was reported between the electronic pain rating scales and their traditional counterparts. Moreover, operated related errors with measurement and calculations on VAS and CAS scores were eradicated in electronic versions of these pain rating scales, increasing validity, and creating a time-saving, cost-effective procedure. ${ }^{7}$ Therefore, in our study, electronic pain rating scales were preferred over conventional versions.

The correlation between different pain rating scores was studied widely and strong correlation was found between VAS, and NRS, ${ }^{8,21}$ VAS, and CAS, ${ }^{22} \mathrm{CAS}$, and FRS, $^{23}$ VAS, and FRS. $^{24}$ Similar findings were presented in our study showing a positive correlation between all four electronic pain rating scales. The high correlation suggested interchangeability between all methods according to patients' needs. Although VAS and NRS demonstrated similar sensitivity results in patients with acute pain, ${ }^{25}$ elderly patients with age around 75 reported to fail to complate the VAS scale when compared to NRS. ${ }^{8}$ However, the mean age value in our study was $36 \pm 13.09$ and the oldest patient was 69. Moreover, no patients experienced any problem while completing the four pain rating scales. The use of the VAS scale was reported to be difficult in patients who were not familiar with the scale. Therefore, the compliance level in pain rating with VAS might be rather low. ${ }^{7}$ On the other hand, CAS has united VAS features with gradual color and width change through the scale bar and thus eliminating the difficulties in compliance with VAS. ${ }^{10,11}$ That might be the reason for its very strong correlation and good agreement level with NRS. NRS was reported with good compliance and ease of use and being applicable even verbally. ${ }^{7}$ CAS was reported to be a valid and reliable scale for pain intensity measurement in pediatric patients with acute pain. ${ }^{11,23}$ This might prove useful for this scale to be used in patients with symptomatic teeth for pain assessment. Yet to the best of the authors' knowledge this is the first study reporting a comparison of CAS with other pain rating scales in adult patients with symptomatic teeth. Although FRS was created mainly with pediatric means, the use of this system with patients with acute pain or elderly patients proved to be beneficial and have a high compliance level., ${ }^{71}$ In previous studies, the reliability, and validity of FRS to measure pain intensity on adults ${ }^{26,27}$ were reported and its compliance with $\mathrm{NRS}^{26,28}$ and $\mathrm{VAS}^{26}$ scale was supported. The use of 6,7 , or 11 faces FRS scales was proved to be reliable and in good compliance with NRS. $^{26,28}$

Although the agreement level between CAS and NRS was good, the agreement level between all four scales was only moderate. A previous study, evaluating agreement level on pain reduction percentage reported a similar agreement level between VAS and NRS on a moderate level. ${ }^{29}$ The lowest values were between FRS and other scales probably due to its lack of sensitivity with the simplistic structure of FRS including 6 grades (6 faces) to describe the pain. Moreover, there is an argument that the change of faces in different parts of the scale may not be equal to each other. ${ }^{30}$ However, this simplicity is needed to make it feasible for young people and adults with low compliance level such as patients with acute pain. ${ }^{14-16}$ Therefore, choosing different scales according to patients' needs is crucial for the benefit of the patient. According to the results of this study all four electronic pain rating scales can be used interchangeably in patients with dental pain.

\section{CONCLUSIONS}

A strong correlation with a moderate level of agreement is present between all four electronic pain rating scales providing interchangeability between scales and enabling dentists to choose the best suitable scale for patients with symptomatic teeth.

\section{REFERENCES}

1. Griffin SO, Jones JA, Brunson D, Griffin PM, Bailey WD. Burden of oral disease among older adults and implications for public health priorities. Am J Public Health 2012; 102(3): 411-418

2. Rosas S, Paço M, Lemos C, Pinho T. Comparison between the Visual Analog Scale and the Numerical Rating Scale in the perception of esthetics and pain. Int Orthod 2017; 15(4): 543-560 
3. O’Keefe EM. Pain in endodontic therapy: preliminary study. J Endod 1976; 2: 315-319

4. Bergenholtz G. Inflammatory response of the dental pulp to bacterial irritation. J Endod 1981; 7: 100 104

5. Odai ED, Ehizele AO, Enabulele JE. Assessment of pain among a group of Nigerian dental patients. BMC Res Notes 2015; 19; 8:251

6. Gracely RH, McGrath F, Dubner R. Ratio scales of sensory and affective verbal pain descriptors. Pain 1978; 5: 5-18

7. Haefeli M, Elfering A. Pain assessment. Eur Spine J 2006; 15 Suppl 1: S17-24

8. Kremer E, Atkinson JH, Ignelzi RJ. Measurement of pain: patient preference does not confound pain measurement. Pain 1981; 10: 241-248

9. Revill SI, Robinson JO, Rosen M, Hogg MI. The reliability of a linear analogue for evaluating pain. Anaesthesia 1976; 31(9): 1191-1198

10. McConahay T, Bryson M, Bulloch B. Defining mild, moderate, and severe pain by using the color analogue scale with children presenting to a pediatric emergency department. Acad Emerg Med 2006; 13(3): 341-344

11. Bulloch B, Garcia-Filion P, Notricia D, Bryson M, McConahay T. Reliability of the Color Analog Scale: Repeatability of Scores in Traumatic and Nontraumatic Injuries. Acad Emerg Med 2009; 16(5): 465-469

12. Paice JA, Cohen FL. Validity of a verbally administered numeric rating scale to measure cancer pain intensity. Cancer Nurs 1997; 20(2): 88-93

13. Farrar JT, Young Jr JP, LaMoreaux L, Werth JL, Poole RM. Clinical Importance of Changes in Chronic Pain Intensity Measured on an 11-point Numerical Pain Rating Scale. Pain 2001; 94(2): 149-158

14. Wong DL, Baker CM. Pain in children: comparison of assessment scales. Pediatr Nurs 1988; 14(1): 9-17

15. Bulloch B, Tenenbein M. Assessment of clinically significant changes in acute pain in children. Acad Emerg Med 2002; 9(3): 199-202

16. Jones KR, Vojir CP, Hutt E, Fink R. Determining mild, moderate, and severe pain equivalency across pain-intensity tools in nursing home residents. $J$ Rehabil Res Dev 2007; 44(2): 305-314

17. Landis JR, Koch GG. The measurement of observer agreement for categorical data. Biometrics 1977; 33(1): 159-174

18. Jamison RN, Gracely RH, Raymond SA, et al. Comparative study of electronic vs. paper VAS ratings: a randomized, crossover trial using healthy volunteers. Pain 2002; 99: 341-347

19. Sánchez-Rodríguez E, de la Vega R, Castarlenas E, Roset R, Miró J. An APP for the Assessment of Pain Intensity: Validity Properties and Agreement of Pain Reports When Used with Young People. Pain Medicine 2015; 16(10): 1982-1992

20. Castarlenas E, Sanchez-Rodriguez E, de la Vega R, Roset R, Miro J. Agreement between verbal and electronic versions of the numerical rating scale (NRS-11) when used to assess pain intensity in adolescents. Clin J Pain 2015; 31: 229-34

21. Jensen MP, Karoly P, Braver S. The measurement of clinical pain intensity: a comparison of six methods. Pain 1986; 27: 117-126

22. McGrath PA, Seifert CE, Speechley KN, Booth JC, Stitt L, Gibson MC. A new analogue scale for assessing children's pain: an initial validation study. Pain 1996; 64(3): 435-443

23. Bulloch B, Tenenbein M. Validation of Two Pain Scales for Use in the Pediatric Emergency Department. Pediatrics 2002; 110(3): e33

24. Fadaizadeh L, Emamai H, Samii K. Comparison of visual analogue scale and faces rating scale in measuring acute postoperative pain. Arch Iran Med 2009; 12(1): 73-75

25. Breivik EK, Björnsson GA, Skovlund E. A comparison of pain rating scales by sampling from clinical trial data. Clin J Pain 2000; 16: 22-28

26. Stuppy DJ. The faces pain scale: Reliability and validity with mature adults. Applied Nursing Research 1998; 11(2): 84-89

27. Herr KA, Mobily PR, Kohout FJ, Wagenaar D. Evaluation of the faces pain scale for use with the elderly. Clinical Journal of Pain 1998; 14: 29-38

28. Kim EJ, Buschmann MT. Reliability and validity of the Faces Pain Scale with older adults. Int $J$ Nurs Stud 2006; 43(4): 447-56

29. Pratici E, Nebout S, Merbai N, Filippova J, Hajage D, Keita H. An observational study of agreement between percentage pain reduction calculated from visual analog or numerical rating scales versus that reported by parturients during labor epidural analgesia. Int J Obstet Anesth 2017; 30: 39-43

30. Tomlinson D, von Baeyer CL, Stinson JN, Sung L. A Systematic Review of Faces Scales for the SelfReport of Pain Intensity in Children. Pediatrics 2010; 126: e1168-1198 